\title{
COVID-19'a Karşı Kullanılan Dezenfektanlar ve Toksik Etkileri
}

\section{Disinfectants Used Against COVID-19 and Their Toxic Effects}

\author{
Anıl Yirün ${ }^{1,2}$ \\ ORCID: 0000-0002-4050-8832 \\ Selinay Başak Erdemli Köse ${ }^{1,3}$ \\ ORCID: 0000-0001-8986-585X \\ Pınar Erkekoğlu ${ }^{1}$ \\ ORCID: 0000-0003-4713-7672
}

\begin{abstract}
${ }^{1}$ Hacettepe Üniversitesi, Eczacilık Fakültesi, Farmasötik Toksikoloji Anabilim Dalı Sihhiye 06100, Ankara, Türkiye
\end{abstract}

\section{${ }^{2}$ Çukurova Üniversitesi, Eczacılık Fakültesi, Farmasötik Toksikoloji Anabilim Dalı, 01330 Sarıçam, Adana, Türkiye}

${ }^{3}$ Burdur Mehmet Akif Ersoy Üniversitesi Fen-Edebiyat Fakültesi Kimya Bölümü Biyokimya Anabilim Dalı, Burdur, Türkiye

\section{Corresponding author:}

Pınar Erkekoğlu,

Hacettepe Üniversitesi, Eczacılık Fakültesi, Farmasötik Toksikoloji Anabilim Dalı Sihhiye 06100, Ankara, Türkiye E-mail: erkekp@yahoo.com, erkekp@ hacettepe.edu.tr;

Tel: +9031253052178
Received date : 20.052021

Accepted date : 05.072021
DOI: 10.52794/hujpharm.939541

\section{ÖZET}

Çin'in Wuhan şehrinde 2019 yılının Aralık ayında "Koronavirüs Hastalığı 2019 (COVID-19)" ortaya çıkmıştır ve ardından tüm dünyaya hızla yayılmıştır. Salgının ana bulaşma yolu solunum yolu damlacıklarının kişiler arası bulaşı nedeniyle olsa da virüsün temas ettiği yüzeylerde günlerce canlı kalabildiği ve kontamine vücut bölümlerinden ve yüzeylerden de bulaştığı bilindiğinden, dezenfektanlar hızla artan bir şekilde günlük kullanımın bir parçası olmuştur. Ancak, dezenfektanların içerdiği kimyasal ajanlara uzun süreli ve yüksek konsantrasyonlarda maruziyet insan sağlığı ve çevreyi tehdit eden önemli toksik etkiler ortaya çımasına neden olabilir. Bu nedenle, dezenfektanların doğru kullanılması ve olası toksik etkilerle ilgili olarak sağllk personelinin ve toplumun bilgilendirilmesi büyük önem taşımaktadır. Bu derlemede COVID-19 ile mücadelede sık kullanılan dezenfektanlar ve toksik etkileri hakkında bilgi verilmesi amaçlanmıştır. Dezenfektanların toksik etkileri hakkında sağlık personeli ve toplumu bilgilendirmek halk sağlığını korumak açısından büyük öneme sahiptir. Dezenfektanların yüksek konsantrasyonlarda ayrı ayrı veya birlikte kullanıldıklarında oluşabilecek potansiyel sağlık tehlikelerine karşı önlemler alınmasını gerekmektedir. Bu derlemede, COVID-19 pandemisi esnasında sıklıkla kullanılan dezenfektanların olası toksisiteleri hakkında bilgi aktarılacaktır.

Anahtar Kelimeler: Koronavirüs, COVID-19, pandemi, dezenfektan, toksisite

\section{ABSTRACT}

Coronavirus Disease 2019 (COVID-19) emerged in Wuhan, China in December 2019 , and then spread rapidly all over the world. Although the main transmission route of the pandemic is through the transfer of respiratory droplets among people, it is known that the virus can survive for days on contact surfaces and is also transmitted from body parts and contaminated surfaces. Therefore, disinfectants have increasingly become a part of daily use. However, prolonged exposure to these chemical agents at high concentrations may cause significant toxic effects that threaten human health and the environment. Therefore, it is of great importance to inform the public about the correct use of disinfectants and possible toxic effects. Informing the healthcare personnel and public about the toxic effects of disinfectants has of great importance for protecting public health. Precautions should be taken against the potential health hazards of disinfectants when used separately or in combination. In this review, the possible toxic effects of disinfectants that are frequently used during COVID-19 pandemic will be discussed.

Key Words: Coronavirus, COVID-19, pandemic, disinfectant, toxicity 


\section{GíRiş}

2019 y1lı sonunda hayatımıza giren "koronavirüs hastalığ1 (COVID-19)"na "Şiddetli Akut Solunum Sendromu Koronavirüs 2 (SARS-CoV-2)" virüsü neden olmaktadır. SARS-CoV-2'nin yol açtığ 1 bu pandemi ile dezenfektanların kullanımında tüm dünya genelinde çok büyük bir artış olmuştur. Virüsün enfekte bireyden diğer bireye geçme hızı yüksektir. Virüs, öksürük ve hapşırma ile çevreye yayılan solunum damlacıkları ve aerosollerle bulaşabilmektedir. Ayrıca, kontamine yüzeylerle olan etkileşimlerle de daha düşük hız ve miktarlarda olsa da yayılabildiği bilinmektedir. Virüsün kontamine yüzeylerde günlerce canlı kalabildiği ve enfeksiyonu yaymaya devam edebildiği de gösterilmiştir. Yayılmayı önlemek, kişisel hijyeni sağlamak ve yüzeyler ile toplu kullanıma açık alanların dezenfeksiyonu için etkili birçok dezenfektan ajanlar bulunmaktadır. Ancak, bu dezenfektanların özellikle uzun süre ve yüksek miktarlarda kullanımı ile insan sağlığ ve çevreyi tehdit edebileceği ve ciddi toksik etkilere yol açabileceği göz ardı edilmemelidir. Bu derlemede, COVID-19 pandemisi ile mücadelede sık kullanılan dezenfektanların toksik etki mekanizmaları ve toksik etkileri hakkında bilgi verilmesi amaçlanmıştır.

\section{COVID-19 PANDEMISİ}

Dünya 2002-2003 yılları arasında "Ciddi Akut Respiratuvar Sendromu (SARS)" salgınlarını atlatmıştır. SARS'a neden olan virüs "SARS-CoV" olarak isimlendirilmiştir. 2011 yılında ise "Orta Doğu Respiratuvar Sendromu (MERS)" ortaya çıkmıştır. MERS'e yol açan virüs ise, "MERS-CoV" olarak adlandırılmıştır. Her iki virüs de koronavirüslerin Betacoronavirüs cinsindendir ve zoonatik oldukları düşünülmektedir. 2019 yılının sonunda ise Çin'in Hubei bölgesindeki Wuhan şehrinde respiratuvar semptomlarla kendini gösteren "COVID-19 hastal1ğı" ortaya çıkmıştır. Bu hastalığa neden olan virüs "SARS-CoV-2" olarak adlandırılmıştır (1). Haziran 2021 'in ortaları itibariyle 175 milyona yakın kişinin hastalığa yakalandığı bilinmektedir (2).

Hastalığın kişiden kişiye geçme hızı oldukça yüksektir $\left(\mathrm{R}_{0}=2,2-2,6\right)$. Klinik tablo bireyler arası farklılıklar göstermektedir. Hastaların \%30'unda hiçbir semptom görülmemiş, ya da hafif belirtiler ortaya çıkmıştır. Kalan hastaların bir kısmı orta-hafif belirtiler gösterirken, özellikle kronik hastalıkları (di- yabet, hipertansiyon, kalp hastalıkları) ve immün yetmezliği olan, diyabetli, kalp damar hastalığı olan veya obez bireylerde hastalığın ciddi belirtilerle ortaya çıktı̆̆ belirlenmiştir (3).

Hastalık esnasında meydana gelen sitokin firtınas1 sonucu tablo ilerleyebilmekte ve ölümler ortaya çıkabilmektedir. Şu an hastalık semptomatik olarak tedavi edilmektedir. Tedavide antiviral ilaçlar (favipiravir gibi), gerekli ise antibiyotikler (azitromisin gibi), kortikosteroidler ve $\mathrm{C}$ vitamin infüzyonu gibi farklı seçenekler kullanılmaktadır (4).

Koronavirüs, ortalama $120 \mathrm{~nm}$ çapında küresel bir şekle sahiptir. Virüs zarfı, glikoproteinler (dışarıya çıkınt1 yapan "spike"lar) ve transmembran proteinlerle çevrelenmiş çift tabakalı bir lipit yapıdır $(3,5)$. Spike proteinler, virüsün hücre yüzeyine yapışmasını ve enfekte hücrelere girmesini sağlamaktadır. Lipit membran, daha sonra hücre içinde kopyalanan virüsün genetik RNA kodunu sarmaktadır. Virüs zarının yapısal bütünlüğü, zar proteinlerinin tanımlanmış topolojisi ve üçüncül yapısı ve virion genomunun korunmuş yapısı ve aktivitesi, virüsün bulaşıcıllı̆ $\breve{g}_{1}$ için kritik faktörlerdir. Bu nedenle, bu yapılarda meydana gelecek bir önemli hasar veya bozulma, virüsü etkisiz hale getirmekte ve bulaşıcılığını önler önlemektedir (6).

Yapılan çalışmalarda SARS-CoV-2 virüsünün genomunun sekansı belirlenmiştir. $\mathrm{Bu}$ virüsün genom sekansinda SARS-CoV ve MERS-CoV'a benzeyen bölgeler olmasına rağmen, farklı bir genom kompozisyonunun olduğu görülmüştür. Tüm bu çalışmalar sonucu hastalığa karşı aşı geliştirilmesinin elzem olduğu görüşü bilim çevrelerinde ön plana çıkmıştır (7).

Aralı 2020 itibariyle ABD'de Amerikan Gida ve İlaç Dairesi (FDA), COVID-19 hastalığına karşı geliştirilen üç aşıya acil kullanım onayı vermiştir ve öncelikli olarak sağlık çalışanları ve risk grupları olmak üzere, bireylerin aşılanması süreci çok sayıda ülkede başlamıştır (8). Diğer taraftan, Avrupa'da Avrupa İlaç Ajansı (EMA) da Avrupa genelinde dört aşıya acil kullanım onayı vermiştir; dört aşıyı da incelemektedir (9). Ülkemizde de Sağlık Bakanlığı şu ana dek üç aşıya acil kullanım onayı vermiştir. Ancak, zamanla ABD, Avrupa ve ülkemiz geneline acil kullanım onayı alacak aşıların sayısının artacağı düşünülmektedir. Ancak, aşıların etkinliği ile ilgili uzun dönem çalışma verileri elde edilmediğinden, aşılar için tekrar dozları gerektiğinden ve toplumsal bağışıklığın kazanılması için henüz çok erken oldu- 
ğundan, COVID-19'a karşı mücadelede hala en iyi seçeceğin dezenfeksiyon ve kişisel hijyenin korunması olduğu görülmektedir. (10).

\section{Yüzeylerin Temizliği ve Dezenfeksi}

Diğer koronavirüsler gibi SARS-CoV-2 de, rotavirüs, norovirüs ve poliovirüs gibi zarfsız virüslere kıyasla dezenfektanlara karşı daha hassas hale gelmesine sebep olan dış lipit zarfına sahip zarflı bir virüstür (11). Ayrıca, SARS-CoV, MERS-CoV ve SARS-CoV-2 gibi Betacoronavirüsler üzerinde yapılan çalışmalar bu virüslerin ultraviyole 1 şı̆̆a (UV) ve yüksek sıcaklığa $\left(30\right.$ dakika, $\left.56^{\circ} \mathrm{C}\right)$ duyarlı olduğunu göstermektedir (12). COVID-19 virüsünün farklı yüzeylerdeki kalıcılığını değerlendiren çalışmalar literatürde mevcuttur $(13,14)$. Bir çalışmada, COVID-19 virüsünün kumaş ve ahşapta 1 güne kadar, camda 2 güne kadar, paslanmaz çelik ve plastikte 4 güne ve tıbbi maskenin dış tabakasında 7 güne kadar yaşayabildiğini bulunmuştur (13). Bir başka çalışmada ise, COVID-19 virüsünün bakır yüzeyde 4 saat, kartonda 24 saat ve plastik ve paslanmaz çelikte 72 saate kadar hayatta kaldığı bulunmuştur (14).

Koronavirüs salgınına karşı hükümetler, yerel yetkililer ve halk sağlığı enstitüleri kamu tesislerinde ve toplum tarafindan paylaşılan alanlarda kitlesel dezenfeksiyon kampanyaları yürütmektedir $(2,4)$. Enfeksiyon olasıllğını en aza indirmek için halk sağlığı kurumları, bireylerin ellerini s1k s1k en az 20 saniye süreyle sabunla yıkayarak veya virüsü öldürerek bulaşıcılığını ortadan kaldırabilen dezenfektanlar kullanarak kişisel hijyen düzeylerini korumalarını teşvik ve tavsiye etmektedir. Alışveriş arabaları, asansör düğmeleri, kapı kolları gibi çok sayıda kullanıc1ya açık olan ürünler, virüsün bulaşması için yüksek riskli alanlar olarak kabul edilir ve bu nedenle, etkili biyosidal maddelerle sürekli sterilize edilmeleri gerekmektedir (15).

Dezenfektanlar ve antiseptikler, yüzeyleri ve boşlukları sterilize etmek için yaygın olarak kullanılmaktadır. Dezenfektan mikrobiyal enfeksiyon ajanlarını tamamen öldürüp ortadan kaldırdığında bir alan veya cihaz sterilize edilmiş olarak kabul edilmektedir (16). Bir dezenfektanın bir mikroorganizmayı deaktive etme yeteneği, içindeki kimyasal madde veya maddelerin etki şekline, patojenin yüzeyinin moleküler yapısına ve hücre içi savunma sistemlerinin etkinliği ile ilişkilendirilmektedir (17).
Yüzeylerin mekanik olarak temizlenmesi, patojenleri gidermeye veya kirlenmiş yüzeylerdeki viral yükü önemli ölçüde azaltmaya yardımcı olmaktadır ve herhangi bir dezenfeksiyon işleminde ilk adımdır. $\mathrm{Su}$, sabun (veya nötr bir deterjan) ve bir tür mekanik işlemle (firçalama veya sıvı püskürterek yıkama) temizlik, kir, birikintiler ve kan gibi diğer organik maddeleri gidermekte ve azaltmaktadır; ancak, mikroorganizmaları öldürmemektedir (18). Amerikan Ulusal Çevre Koruma Ajansı (US EPA) koronavirüslere karşı kullanılabilecek uygun dezenfektanları ve bunların etkili olması için gerekli uygun temas sürelerini yayınlamıştır (19).

Dezenfektan çözeltileri, üreticinin hacim ve temas süresi önerilerine göre hazırlanmalı ve kullanılmalıdır. Hazırlama sırasında yetersiz seyreltme içeren konsantrasyonlar (çok yüksek veya çok düşük) etkinliklerini azaltabilmektedir. Yüksek konsantrasyonlarda hazırlanan dezenfektanlar ise, kimyasal maruziyeti arttırmakta ve uygulanan yüzeylere de zarar verebilmektedir (18). EPA'ya Göre SARS-Cov-2 için uygun dezenfektanlar ve virüsün yok edilmesi için gerekli temas süreleri Tablo 1'de verilmiştir.

Tablo 1: EPA'ya Göre Sars-Cov-2 İçin Uygun Dezenfektanlar ve Virüsün Yok Edilmesi için Gerekli Temas Süreleri (19).

\begin{tabular}{ll}
\hline Dezenfektan & Temas Süresi \\
\hline Etanol & 30 saniye \\
Kuaterner amonyum + etanol & 1 dakika \\
Kuaterner amonyum + izopropil alkol & 30 saniye \\
Sodyum hipoklorit + sodyum karbonat & 30 saniye \\
Oktanoik asit & 2 dakika \\
Hidrojen peroksit + peroksiasetik asit & 1 dakika \\
Peroksiasetik asit & 1 dakika \\
Sodyum hipoklorit & $1-5$ dakika \\
Gümüş iyonu + sitrik asit & 1 dakika \\
Fenolik dezenfektanlar & $5-10$ dakika \\
& (içerdiği miktara göre \\
Kuaterner amonyum & değişir) \\
& 1 -10 dakika \\
Kuaterner amonyum+trietilen glikol & (içerdiği miktara göre \\
Hidrojen peroksit & dakika \\
L-laktik asit & 5 dakikika \\
Hidrojen peroksit+amonyum & $5-6$ dakika \\
karbonat+Amonyum bikarbonat & \\
Glikolik asit & 10 dakika \\
Hipokloröz asit & 10 dakika \\
\hline
\end{tabular}




\section{Sert (Poröz Olmayan) Yüzeyler}

$\mathrm{Bu}$ tip yüzeyler, su, sabun veya deterjanla temizlenebilmektedir. Dezenfeksiyon için EPA'ya kayıtlı dezenfektanların kullanımı tercih edilmelidir. Dezenfektanlar en az 1 dakika süresince temas yüzeylerinde kalmalıdır. Kullanılacak dezenfektanların son kullanma tarihine dikkat edilmelidir. Dezenfektanları uyguladıktan sonra ortamın havalandırılmasına dikkat edilmelidir. Diğer taraftan, uygun şekilde seyreltilmiş çamaşır suyu (en az 1000 ppm sodyum hidroksit içeren) dezenfeksiyon için kullanılabilmektedir. Çamaşır suyunun da son kullanma tarihine dikkat edilmelidir. Son kullanma tarihi geçmiş çamaşır suyu coronavirüslere karşı etkin olmaz. Evde kullanılan dezenfektanlar ve çamaşır suyu asla amonyak ile karıştırılmamalıdır $(20,21)$.

\section{Yumuşak (Poröz) Yüzeyler}

Halı, kilim, tekstiller gibi kontaminasyonun olabileceği tüm yüzeylerde yine yukarıda belirtilen dezenfektanları içeren temizleyiciler kullanılabilecek en yüksek sıcaklıktaki su ile yıkanarak veya silinerek ve de uygun dezenfektan süreleri dikkate alınarak temizlenebilmektedir. Takiben kurutulabilmektedir $(20,21)$.

\section{Elektronik Eşyalar}

Tabletler, dokunmatik ekranlar, klavyeler gibi elektronik eşyalar yüzeyleri uygunsa etanol bazlı sprey dezenfektanlar sıkılarak ve 30 saniye beklendikten sonra kuru kâğıt havlu ile silinerek veya etanol içeren 1slak mendiller kullanılarak temizlenebilmektedir. Eğer elektronik eşya spreyleme ile bozulacaksa spreyleme yapılmamalı, etanol içeren islak mendillerle silinmelidir $(20,21)$.

\section{DEZENFEKTANLARIN OLASI TOKSİK ETKILLERİ}

COVID-19 dünyaya yayılırken, kullanımı her geçen gün artan kimyasal dezenfektanların (özellikle klorlu maddeler ve deterjanlar uzun süreli kullanımı insan sağlığı ve ekosistemlerde dünya çapında ikincil felaketlere yol açabilmektedir. En sık kullanılan dezenfektan ajanlar olan alkoller, hidrojen peroksit, sodyum hipoklorit, glutaraldehit ve kuarterner amonyum bileşiklerine maruziyet hakkında yapılmış kapsamlı araştırmalar bulunmaktadır. Tüm bu dezenfektanlara düzenli ve sık maruziyet sonucu bireylerde kronik obstrüktif akciğer hastalığı, astım gibi solunum sistemi hastalıklarında artış ve gözde ve deride irritasyon riski bildirilmiştir (22-24). Dezenfekte edilmiş bir yüzeyde kalan kimyasal kalıntılar buharlaşmakta ve solunabilmektedir. Bu tip maruziyetler, genellikle astımlı, alerjik veya hassas kişiler için kötü iç mekan hava kalitesine katkıda bulunmaktadır (25). Bu kalıntılar kansere, üreme bozukluklarına, solunum rahatsızlıklarına, göz ve cilt irritasyonuna, santral sinir sistemi (SSS) bozukluklarına, oksidatif hasara ve daha birçok toksik etkiye neden olmaktadır (26).

Dezenfektanlar küçük (moleküler ağırlık <500 Da) ve orta derecede lipofilik ( $\log \mathrm{P} 1-4)$ moleküllerdir. Cilde nüfuz ederek doğrudan bir cilt reaksiyonu başlatabilmektedirler. Çeşitli dezenfektanlara karşı enflamasyon, likenifikasyon, renk değişikliği ve hatta nekroz gibi geniş kapsamlı deri reaksiyonları gelişebilmektedir. Dezenfektanlar da birçok antimikrobiyal ajanın mikroorganizmaların protein yapısında ve lipit zarında oluşturduğu reaksiyonlara benzer şekilde epidermal keratin filamentleri ve lipitlerle reaksiyona girebilmektedir. $\mathrm{Bu}$ durum herhangi bir istenmeyen reaksiyonu şiddetlendirmek için kimyasalların cildin daha derin cilt katmanlarına nüfuz etmesini de kolaylaştırabilmektedir (27). Dezenfektanların olası dermal toksik etkileri Şekil 1'de özetlenmiştir.

COVID-19 salgını sırasında, sosyal medya platformlarında koronavirüslere karşı dolaşan çok sayıda söylenti ve yanlış bilgi nedeniyle insanlar paniğe kapılmış, anksiyete ve korku içinde yanlış ve aşırı eylemlerde bulunmuşlardır. Bazı bireylerin ciltlerine önerilenden çok yüksek miktarlarda dezenfektan uyguladığ1; gıda ürünlerini çamaşır suyu ve el dezenfektanı gibi ağır dezenfektanlarla yıkadığı bildirilmiştir. Hatta az sayıda da olsa dezenfektanları içenler olduğu da bildirilmiştir. Bu tür aşırı eylemler son derece tehlikelidir ve kalıcı körlük, nöbetler, koma, sinir sisteminde kalıcı hasar ve ölüm gibi sonuçlara neden olabilmektedir (28). Dezenfektanların nörotoksik etkileri Şekil 2'de özetlenmiştir.

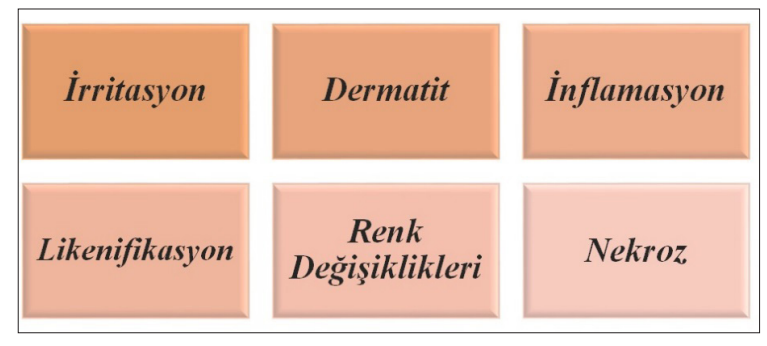

Şekil 1. Dezenfektanların olası dermal toksik etkileri. 


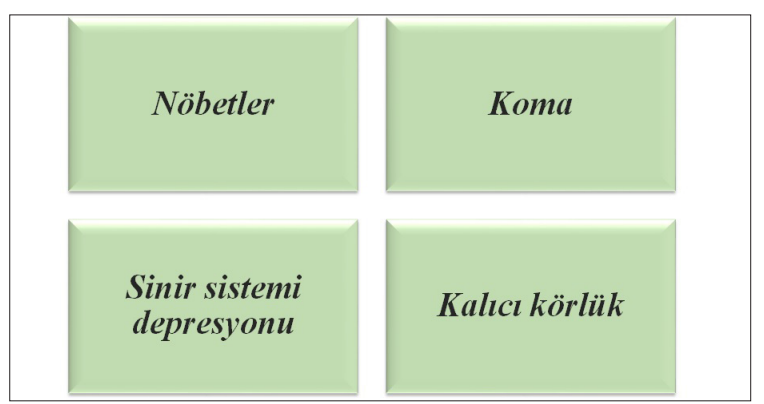

Şekil 2. Dezenfektanların olası nörotoksik etkileri

İnsanların evlerini ve çevrelerini temizlemek için aynı anda birkaç çeşit dezenfektanı birlikte kullandıkları da bilinmektedir. Tehlikeli dumanlar/ gazlar oluşabileceğinden, farklı temizlik ürünlerinin karıştırılması sonucu ciddi istenmeyen etkiler ortaya çıkabilmektedir. Bu gazlara kronik maruziyet astım ve kronik bronşiti indükleyebilmektedir (29). Klorlu ağartıcıların amonyak bazlı temizleyicilerle karıştırılması, kloraminlerin ve muhtemelen uçucu hale gelebilen amonyağın üretimine neden olmaktadır (30). Öte yandan, ağartıcı asit bazlı bir temizleyici ile karıştırıldığında, gaz halindeki klorin veya hipokloröz asit açığa çıkabilmekte ve bu gazlar küçük miktarlarda solunduğunda akut akciğer hasarına neden olabilmektedir $(31,32)$. Ayrıca, klorlu dezenfektanlar azot ile birleşerek kanserojen olarak tanımlanan kloramin veya $\mathrm{N}$-nitrosodimetilamin oluşturabilmektedir (32). Çamaşır suyu ve alkolün karıştırılması, solunduğunda veya deri ile temas ettiğinde toksik ve tehlikeli olan kloroform oluşturmaktadır (29). Bu durumların önüne geçmek için, dezenfektanların toksik etkileri hakkında kamuya açık alanlarda uygun bilgiler bulunması faydalı olacaktır. Kombinasyon halinde kullanıldığında, potansiyel sıçrama tehlikeleri için deri ve göz koruması takmak, yeterli havalandırma sağlamak ve kimyasalları çocukların ve evcil hayvanların erişemeyeceği yerlerde saklamak ve kullanmak da alınması gereken önlemlerdir (33).

Çevreye ve insan sağlığına düşük risk oluşturan dezenfeksiyon için uzun süre etkili bir protokol sağlamak gerekli görünmektedir. Bu bakımdan SARS-Cov-2 virüsüne karşı daha düşük toksik etkiye sahip dezenfektanların kullanılması iyi bir alternatif olabilmektedir. Elleri ve yüzeyleri dezenfekte etmek için dezenfektanların önerilen minimum konsantrasyonları kullanılmalıdır. Yeterli etkinlikte minimum konsantrasyonda dezenfektan kullanmak, bu bileşiklerin akut ve kronik sağlik etkilerini önleyebilmekte ve azaltabilmektedir (34).
Kimyasal dezenfektanların kullanıcılar ve diğer temas eden bireyler için toksik etkileri olabileceğinden dikkatli bir şekilde ve kullanım talimatlarına uygun olarak kullanılmalıdır.

\section{a. Alkoller}

Etanol ve izopropanol, geniş bir bakteri, virüs ve mantar spekturumunda dezenfektan olarak kullan1lan ana alkollerdir. Bu alkollerin biyosidal aktivitesi, konsantrasyonlarına ve hidroafinitelerine bağlıdır. Antimikrobiyal aktivite için optimal konsantrasyon $\%$ 60-80'dir. Rotavirüs, insan immün yetmezlik virüsü (HIV) ve koronavirüsler gibi hidrofilik virüslere karşı etanol izopropanolden daha üstünken, poliovirüs ve hepatit A virüs (HAV) gibi lipofilik virüslere karşı izopropanol daha etkindir. Etanol ve izopropanol \%70-90 konsantrasyonlarda koronavirüsü 30 saniye içinde yok edebilmektedir $(11,15,35,36)$.

Alkollerin viral RNA'ya zarar vermesinin yanı sıra membran hasarına ve virüs proteinlerinin denatüre olmasına neden olduğuna inanılmaktadır. Bu alkollerin güçlü hidrojen bağı oluşturma yeteneği ve amfoterik doğaları, virüs yapısı içindeki molekül içi hidrojen bağlarını kırarak proteinlerin üçüncül yapısını bozmalarını sağlamaktadır (5).

Güçlü antibakteriyel ve antiviral etkileri nedeniyle sıklıkla dezenfektanlarda tercih edilen alkoller insan sağlığına da zarar verebilmektedir. Deri, göz, burun ve boğazda irritasyona yol açabilmektedir. Özellikle spreylemeyle sıkılan el dezenfektanları havadaki damlacıkların ağız yoluyla alınması sonucunda solunum yollarında irritasyona neden olabilmektedir. İzopropil alkol ve metaboliti aseton, SSS'de depresyona neden olmaktadır. Zehirlenme yutma, soluma veya cilt emiliminden kaynaklanabilmektedir. İzopropil alkol zehirlenmesi belirtileri arasında kızarma, baş ağrısı, baş dönmesi, SSS depresyonu, bulant1, kusma, anestezi, hipotermi, düşük tansiyon, şok ve solunum depresyonu bulunmaktadır. Cilde düzenli olarak etanol uygulanmasından sonra (örneğin, el dezenfektanları) nispeten düşük ancak ölçülebilir kan etanol ve metaboliti olan asetaldehit konsantrasyonları oluşabilmektedir. Ancak, çok yoğun kullanımlarda bile bu kan düzeyleri akut toksisite oluşturacak düzeye ulaşmaz. Sadece çocuklarda, özellikle irritasyona uğramış deriye temasla akut toksisite oluşma riski bulunmaktadır $(18,22,37)$. Alkollerin insanlarda olası toksik etkileri Şekil 3'de özetlenmiştir. 


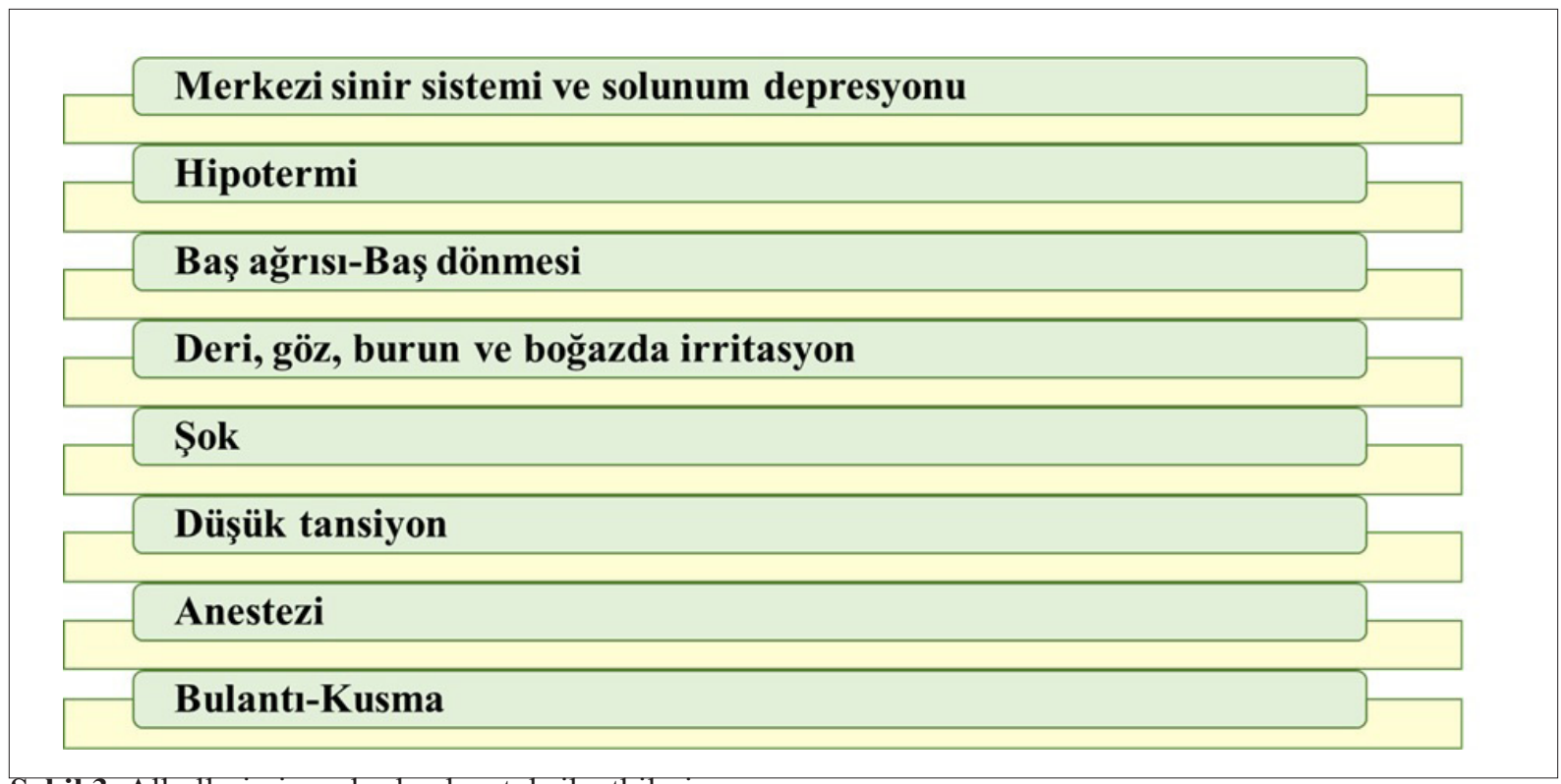

Şekil 3. Alkollerin insanlarda olası toksik etkileri.

\section{b. Kuaterner Amonyum Bileşikleri}

Kuaterner amonyum bileşikleri yaygın olarak kullanılan etkili dezenfektanlardır. Bu bileşikler, katyonun nitrojen atomu üzerinde dört organik sübstitüente sahip bir amino grubu ve anyonun bir halojenür veya bir sülfat olduğu organik bazlı tuzlardır. Amino grubu üzerinde sübstitüent olarak alkil zincirleri, aril grupları ve/veya heterosiklik bileşiklerin kombinasyonu, bu bileşiklere geniş bir aktivite ve uygulanabilirlik yelpazesi sağlamaktadır. Genellikle sübstitüentlerden biri uzun alkil zinciriyken, diğer üçü daha küçük moleküllerdir. Bu şekildeki bir yapı, misellerin oluşumuyla patojenlerin hücre membranlarının parçalanmasını, dolayısıyla yapısal bütünlüklerinin kaybını kolaylaştırmaktadır $(5,15,38)$.

Biyosidal bir ajan olarak yaygın olarak kullanılan kuaterner amonyum bileşiklerinden biri, alkil dimetil benzil amonyum klorürdür. \%1'den daha az konsantrasyonda ve bir dakika veya daha kısa bir maruz kalma süresi içinde koronavirüslere karşı etkindir (5, $15,38)$.

Katyonik yüzey aktif bileşikler genel olarak anyonik ve iyonik olmayan sürfaktanlardan daha toksiktir. Lipit zarlarındaki fosfolipitleri ve kolesterolü çözmeleri nedeniyle, kuaterner amonyum bileşikleri membran geçirgenliğini bozarak hücre ölümüne neden olabilmektedir. Bozulmamış deri üzerinde irritan etki oluşturmayan maksimum konsantrasyonun $\% 0,1$

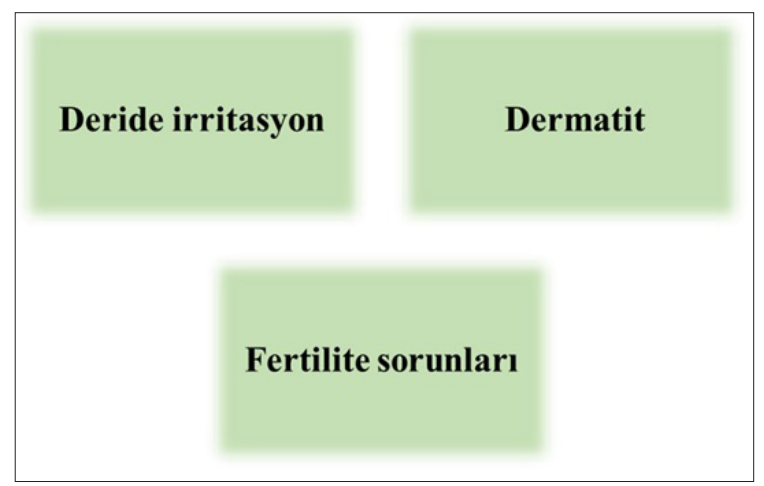

Şekil 4. Kuaterner amonyum bileşiklerinin insanlarda olası toksik etkileri

olduğu ve \%1-10 konsantrasyonda ciltte irritasyona neden oldukları gözlenmiştir. \%0,1'in altındaki konsantrasyonlar, kontakt dermatit veya hasarlı deriye sahip kişilerde irritasyona neden olabilmektedir (18, 22, 37). Kuarterner amonyum bileşiklerinin erkek ve dişilerde üreme sisteminde toksik etki yapabilecekleri ve fertilite sorunlarına neden olabilecekleri gösterilmiştir (39). Kuaterner amonyum bileşiklerinin insanlarda olası toksik etkileri Şekil 4'de özetlenmiştir.

\section{c. Aldehitler}

Genel olarak, aldehitler irritan kimyasal maddelerdir ve yapılarına klorun eklenmesi genellikle oluşturdukları neden oldukları irritasyonun derecesini 
arttırmaktadır. Formaldehit ve glutaraldehit tıbbi cihazlar ve cerrahi ekipman için yüksek seviye dezenfektanlar olarak bilinmektedir (17). Bu aldehitler, bakterileri ve virüsleri proteinlerini ve nükleik asitlerini alkile ederek deaktive etmekte ve maruziyetten sonraki 2 dakika içinde \%0,5-3 konsantrasyon aral1ğında koronavirüse karşı etkilidirler (5).

Çeşitli halojenlenmiş aldehitlerin mutajenik özellikleri hakkında önemli veriler bulunmaktadır. Kloroasetaldehit, DNA ile etkileşimi türleri açısından kapsamlı bir şekilde incelenmiştir. Özellikle gluteraldehitin deri ve solunum sisteminde hassaslaştırıcı etkileri olduğu görülmüştür. Akut veya kronik maruziyet cilt irritasyonuna veya dermatite, mukoza zarlarında irritasyona (göz, burun, ağız) veya pulmoner fonksiyon bozukluklarına neden olabilit olabilmektedir. Glutaraldehite maruz kalan sağlık çalışanlarında burun kanaması, alerjik kontakt dermatit, astım ve rinit de bildirilmiştir (40-42).

Formaldehit, bilinen en toksik aldehit türevlerindendir ve solunum yollarında irritasyona yol açmaktadır. Laboratuvar çalışmalarında formaldehit maruziyetinin sıçanlarda nazal kansere neden olabileceği tespit edilmiştir. Uluslarası Kanser Araştırma Ajansı (IARC) tarafindan "Grup I karsinojen (insanda kesin karsinojen)" olarak sınıflandırılmıştır. Yüksek derecede formaldehit maruziyeti ciddi toksisite ve hatta letaliteye yol açabilmektedir. Anatomistler ve cenaze defin işlemleri gibi yüksek düzeyde formaldehit buharına maruz kalan işlerde çalışanlar genel popülasyonla karşılaştırıldığında daha yüksek bir lösemi ve beyin kanseri riski altında olduklarını ortaya koyan bulgular elde edilmiştir (43). Mesleki olarak formaldehite maruz kalma potansiyeli olan sektörlerdeki 25.619 işçi üzerinde yapılan bir çalışmada, formaldehite maruz kalan işçiler arasında lösemiye, özellikle miyeloid lösemiye bağlı ölüm riskinin arttığı gösterilmiştir. Aynı işçi grubu üzerinde 10 y1llık veri ile gerçekleştirilen bir takip çalışması da formaldehit maruziyeti ile hematopoietik ve lenfatik sistem kanserleri, özellikle miyeloid lösemi arasında olası bir bağlantının varlı̆̆ 1 göstermeye devam etmiştir $(44,45)$.

Formaldehite havadan veya deriden düşük düzeylere uzun süre maruz kalmak astım benzeri solunum problemlerine yol açabilmektedir. Ayrıca, dermatit ve kaşıntıya da neden olabilir $(18,22,37)$. Aldehitlerin insanlarda olası toksik etkileri Şekil 5'de özetlenmiştir.

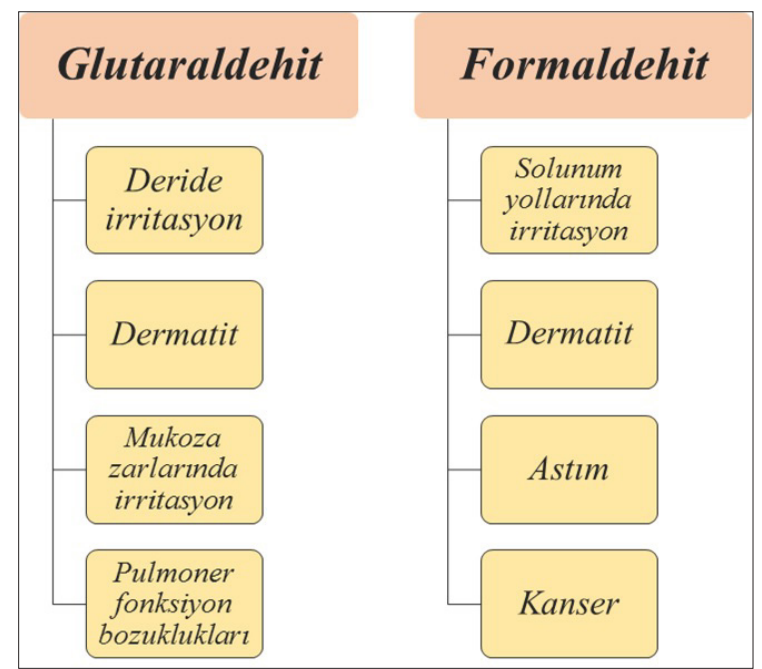

Şekil 5. Aldehitlerin insanlarda olası toksik etkileri.

\section{d. Hipoklorit ve organik klor salıveren bileşikler}

Ev tipi çamaşır suyu, bulunabilirliği, düşük maliyeti, düşük toksisitesi ve geniş spektrumlu biyosidal etkinliği nedeniyle en çok kullanılan evsel dezenfektanlardan biridir. Çamaşır suyunun aktif kimyasal bileşeni, genellikle \%3-6 konsantrasyon aralığında bulunan sodyum hipoklorittir. Düşük $\mathrm{pH}$ (4-7)'da, hipoklorit anyonu protonlanır ve baskın tür olacak olan hipokloröz asit ile dengede bulunmaktadır (15, 38). Asidin, membran geçirgenliği ve membranın lipitlerine ve nükleik asitlere zarar veren güçlü oksitleme kabiliyetinden dolayı aktif biyosidal ajan olduğu düşünülmektedir. Çözeltinin pH'ı arttıkça hipoklorit iyonu baskın hale gelir ve biyosidal aktivite azalmaktadır (46).

Yüksek verimlilikleri, kolay ulaş1labilirlikleri nedeniyle, klorlu bileşikler genellikle bulaşıcı hastalıkların yayılmasını önlemede sıklıkla kullanılan ajanlardır. Bu bileşikler, solunum yolları üzerinde ciddi toksik etkilere sahiptirler ve kısa/uzun vadeli pulmoner komplikasyonlara neden olmaktadır. Özellikle kapalı alanlarda, akut ve yoğun klor gazına maruz kalma, akut ve şiddetli nefes darlığına, hava yolu spazmına ve pulmoner emboliye yol açabilmektedir. Bu komplikasyonlar, bazı durumlarda hastaneye yatışa neden olabilecek kadar şiddetlidir. Uzun süreli tedavi gerektirebilen kronik astım gibi uzun süreli komplikasyonlar da meydana gelebilmektedir (34). Ev tipi ağartıcıda kullanılan konsantrasyondaki sodyum hipoklorit $(\% 5,25-6,15)$ oküler irritasyona, orofaringeal, özofagal ve mide yanıklarına neden olabil- 


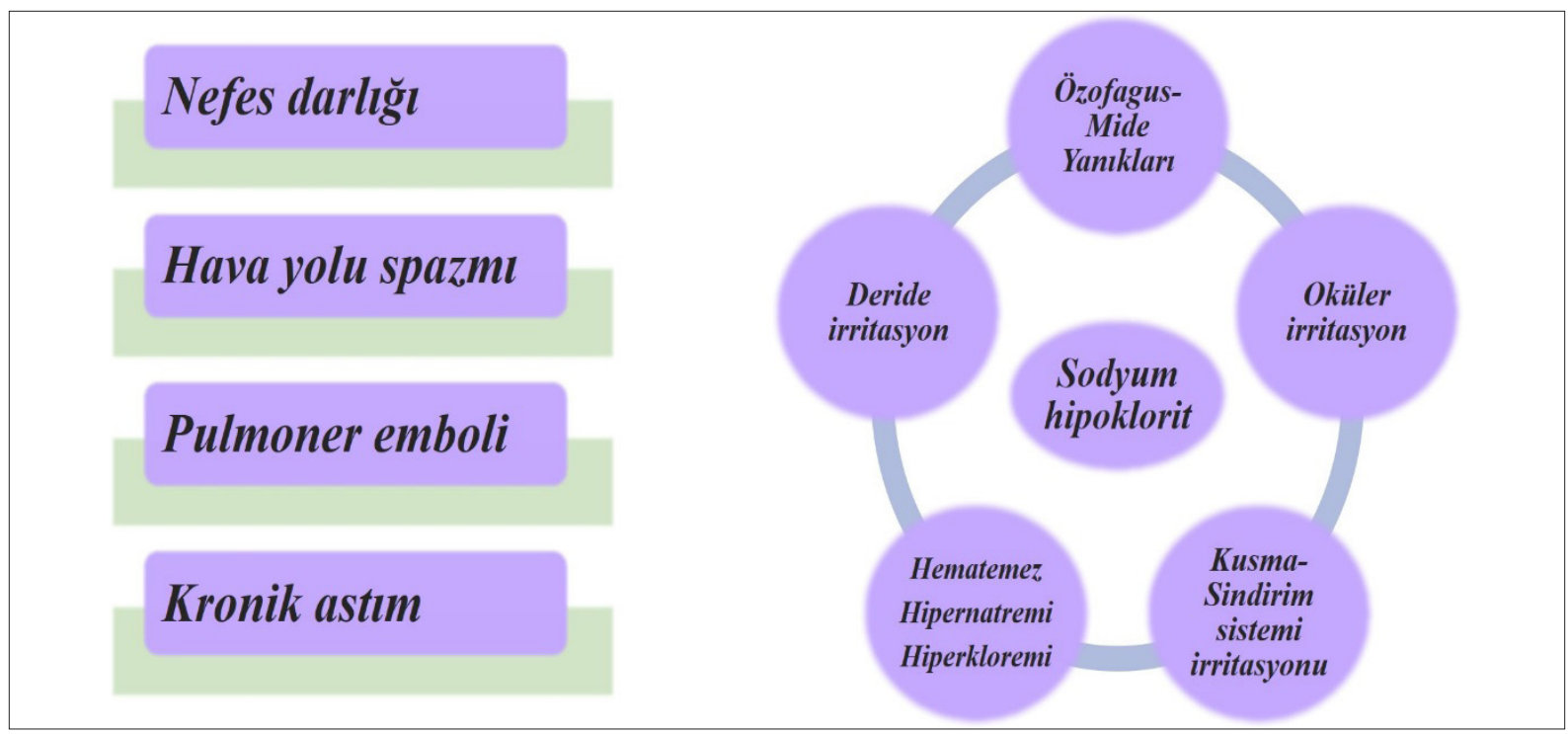

Şekil 6. Hipoklorit ve organik klor salıveren bileşikler insanlarda olası toksik etkileri.

mektedir. Hipokloritler, seyreltilmiş şekilde (\%5-10) göz ve deri irritasyonuna yol açabilmektedir. Konsantre şekilde ise koroziflerdir. Oral temasda kusma ve sindirim sistemi irritasyonu, yüksek miktarlarda maruziyet ile de hematemez, hipernatremi ve hiperkloremi gözlenebilmektedir $(18,22,37)$. Hipoklorit ve organik klor salıveren bileşiklerin insanlarda olası toksik etkileri Şekil 6'de özetlenmiştir.

\section{e. Glikolik Asit}

Glikolik asit, pH'a bağlı olarak güçlü bir irritandır. Glikolat oral yoldan maruziyetle nefrotoksik özellik göstermektedir. Glikolik asitin yol açtığı böbrek toksisitesi, oksalik aside biyotransformasyonundan kaynaklanmaktadır. Oksalik asit, çözünmez kalsiyum oksalat kristalleri oluşturmak için kolaylıkla kalsiyum ile çökmektedir. Renal doku hasarına oksalat kristallerinin yaygın birikimi ve glikolik asidin

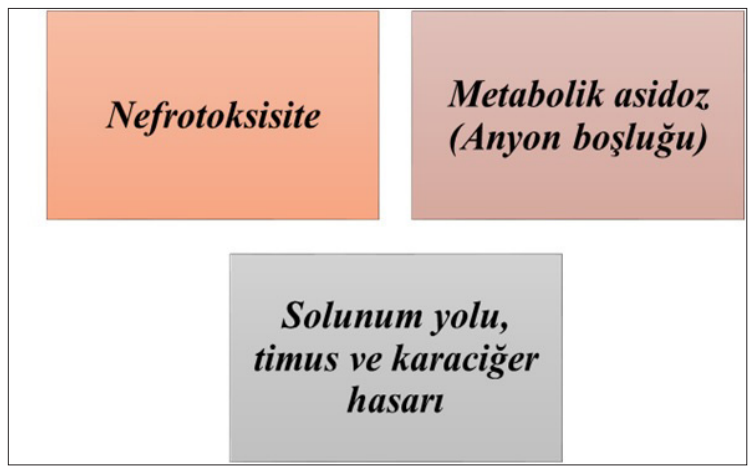

Şekil 7. Glikolik asidin olası toksik etkileri. toksik etkileri neden olmaktadır. Glikolik ve oksalik asit, anyon boşluğu metabolik asidozuna yol açabilmektedir. Glikolik asit uzun süre çok yüksek düzeylerde solunduğunda solunum yolu, timus ve karaciğer hasarına neden olabilmektedir $(18,22,37)$. Glikolik asidin olası toksik etkileri Şekil 7'da özetlenmiştir.

\section{f. Oksitleyici ajanlar}

Hidrojen peroksit ve perasetik asit gibi peroksit bazlı dezenfektanlar, tiyol gruplarının oksidasyonunu ve proteinlerin disülfid bağlarını hedeflemekte ve bu bağları denatüre etmektedir (31). Hidrojen peroksit \%1-3 konsantrasyonlarda virüsidaldir ve SARSCoV'yi bir dakika içinde deaktive edebilmekte; gaz fazında daha da güçlü etki göstermektedir. Perasetik asit, geniş bir patojen spektrumuna karşı ve daha düşük konsantrasyonlarda $(\sim \% 0,3)$ hidrojen peroksitten daha aktiftir; bu nedenle, tıbbi cihazları dezenfekte etmek için sıklıkla kullanılmaktadır. Her iki peroksit bileşiği de lipit membranlar, proteinler ve nükleik asitler dahil olmak üzere virüsün farklı k1sımlarına saldıran hidroksil radikalleri üretmektedir $(17,35)$. Perasetik asit, güçlü bir okside edicidir ve yüksek yüzdelerde aşırı korozyona yol açabilmektedir. Perasetik asit gözlere, solunum yollarının mukoza zarlarına ve cilde irritan özelliktedir. Sadece 3 dakika boyunca $15,6 \mathrm{mg}$ perasetik asit $/ \mathrm{m}^{3}$ (5 ppm) kadar düşük konsantrasyonlara maruz kaldıktan sonra 


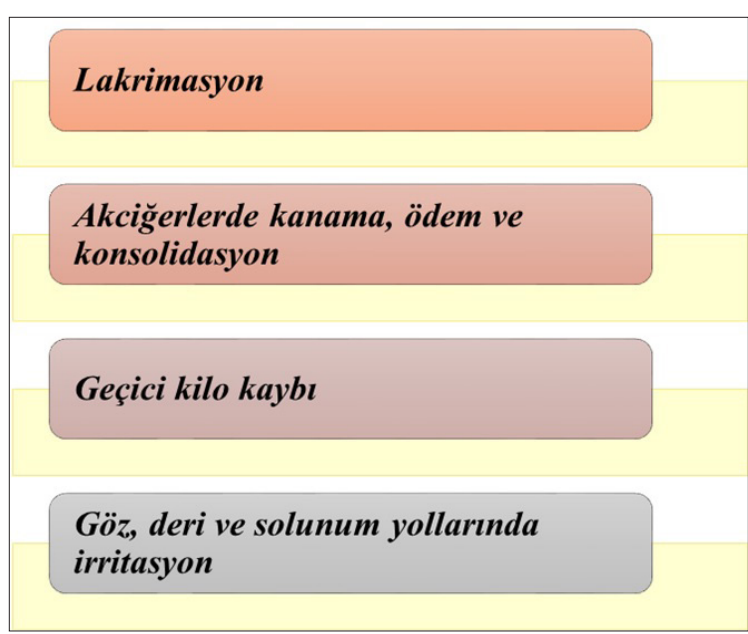

Şekil 8. Perasetik asitin insanlarda olası toksik etkileri.

insanlarda lakrimasyon, aşırı rahatsızlık hissi ve üst solunum yollarında irritasyona neden olabilmektedir. Yüksek konsantrasyonu mortaliteye yol açabilmekte ve akciğerlerde kanama, ödem ve konsolidasyona neden olabilmektedir. Orta ve hafif derecede ve nonletal konsantasyonlarda ise, solunum yolunda irritasyon, geçici kilo kaybı veya azaltılmış kilo alımına yol açabilmektedir $(18,22,37)$. Perasetik asitin insanlarda olası toksik etkileri Şekil 8'de gösterilmiştir.

\section{g. Fenol bazlu dezenfektanlar}

Genellikle, aromatik halka üzerindeki hidrojen atomunun bir alkil grubu veya bir halojen ile yer değiştirdiği sübstitüe fenoller ve bisfenoller "fenol bazlı dezenfektanlar" olarak adlandırılmaktadır (35). Yüksek etkinlikleri nedeniyle, hastane dezenfeksiyonunda kullanılmaktadır (38). HIV gibi virüsler ve diğer hidrofilik virüsleri \%0,5-5 konsantrasyon aralığında dakikalar içinde deaktive edebilmektedir. Bu bileşikler, membran hasarını indükleyerek hücre içi bileşenlerin sızmasına ve proteinlerin denatüre olmasına yol açarak patojenleri etkisiz hale getirmektedir (6).

\section{h. Iyot Saltveren Ajanlar}

İyodoforlar, iyot suda tek başına stabil olmadığından, sulu çözeltilerde bir çözücü madde ile bir iyot kompleksinden oluşan iyot salıcı maddelerdir. Örneğin, povidon-iyot uzun süredir geniş bir bakteri yelpazesi için cilt ve dokular üzerinde antiseptik olarak kullanılmaktadır $(5,40)$. Açığa çıkan elementel iyot, membrana nüfuz edebilmekte ve nükleik asitlere zarar vermenin yanı sıra sülfüril ve disülfür bağlarından proteinlere saldırabilmektedir. Çalışma- lar, povidon-iyodinin süspansiyon halinde SARSCoV'yi \%1 veya daha az konsantrasyonda saniyeler içinde devre dışı bırakabildiğini göstermiştir (47).

\section{i. Sürfaktanlar}

Sürfaktanlar sulu çözelti formunda iyonlaşıp iyonlaşmamalarına göre iyonik ve non-iyonik yüzey aktif maddeler olarak sinıflandırılmaktadır. Suyun yüzey gerilimini düşürmekte, daha derinlere girmesine neden olmakta ve kir ve organik maddelerin uzaklaştırılmasını sağłarłar sağlamaktadır. Deri, göz ve solunum sisteminde irritasyona yol açabilmekte$\operatorname{dir}(18,22,37)$.

\section{SONUÇ}

COVID-19 dünyaya yayılırken, virüsle mücadeleye karşı en önemli ajanlar olan kimyasal dezenfektanların artan ve uzun süreli kullanımı insan sağlığına ve ekosistemlere büyük zarar vermektedir. Bu kimyasal ajanların uygun olmayan şekillerde, yüksek konsantrasyonlarda kullanımları sonucu pek çok toksik etki ortaya çıkabilmektedir.

Yüzeyler ve besin maddelerindeki kalıntılar ile bireylerin kişisel kullanımına bağlı olarak ortamlardaki yüksek dezenfektan konsantrasyonları başta solunum sistemi hastalıkları olmak üzere, göz ve deride irritasyona, deride alerjik reaksiyonlarına, SSS'de hasarlara, uzun vadede birçok doku ve organda oksidatif hasara, üreme sistemi bozuklarına ve kansere yol açabilmektedir. Tüm bu riskleri önlemek adına, dezenfektanların toksik etkileri hakkında kamuyu bilgilendirmek, yüksek konsantrasyonlarda ya da birlikte kullanıldıklarında oluşabilecek potansiyel hasarlara karşı önlemler alınmasını ve sık dezenfekte edilen alanlarda uygun havalandırma koşullarını sağlamak alınması gereken önlemlerdendir.

\section{Kaynaklar}

1. Han Q, Lin Q, Jin S, You L: Recent insights into 2019-nCoV: a brief but comprehensive review. J Infect 2020, 80:373-377.

2. Worldometer. Coronovirus. Retrieved June 10, 2020, from https://www.worldometers.info/coronavirus/

3. Zhu N, Zhang D, Wang W, Li X, Yang B, Song J: A novel coronavirus from patients with pneumonia in China, 2019. N Eng J Med 2020, 382:727-733. 
4. T.C. Sağlık Bakanlığı. Halk Sağglığı Genel Müdürlüğü. Erişkin Hasta Tedavisi. Bilimsel Danışma Kurlulu Çalışması. 7 Mayıs 2021. Retrieved June 10, 2020, from https://covid19.saglik. gov.tr/Eklenti/40719/0/covid-19rehberieriskinhastayonetimivetedavipdf.pdf

5. Kannan S, Shaik Syed Ali P, Sheeza A, Hemalatha K: COVID-19 (Novel Coronavirus 2019) - recent trends. Eur Rev Med Pharmacol Sci 2020, 24(4):2006-2011.

6. Al-Sayah MH: Chemical disinfectants of COVID-19: an overview. J Water Health 2020, 18(5):843-848.

7. Woo PCY, Lau SKP, Chu C, Chan K, Tsoi H, Huamg Y, Wong BHL, Poon RWS, Chai JJ, Luk W, Poon LLM, Wong SSY, Guan Y, Peiris JSM, Yuen K: Characterization and Complete Genome Sequence of a Novel Coronavirus, Coronavirus HKU1, from Patients with Pneumonia. J Virol 2005, 79:884 895.

8. Food and Drug Adminstration (FDA). Covid Vaccines. Retrieved June 10, 2020, from https://www.ema.europa.eu/en/ human-regulatory/overview/public-health-threats/coronavirus-disease-covid-19/treatments-vaccines/covid-19-vaccines

9. European Medicines Agency (EMA). Retrieved June 10, 2020, from https://www.ema.europa.eu/en/human-regulatory/overview/public-health-threats/coronavirus-disease-covid-19/treatments-vaccines/covid-19-vaccines

10. T.C. Sağlık Bakanlığı. COVID-19 Aşısı Bilgilendirme Platformu. Retrieved June 10, 2020, from https://covid19asi.saglik. gov.tr/TR-77708/covid-19-asisi-cesitleri.html

11. Rutala WA, Weber DJ: Best practices for disinfection of noncritical environmental surfaces and equipment in health care facilities: A bundle approach. Am J Infect Control 2019, 47:96105.

12. Rabenau HF, Cinatl J, Morgenstern B, Bauer G, Preiser W, Doerr HW: Stability and inactivation of SARS coronavirus. Med Microbiol Immunol 2005, 194:1-6.

13. Chin AWH, Chu JTS, Perera MRA, Hui KPY, Yen HL, Chan MCW: Stability of SARS-CoV-2 in different environmental conditions. The Lancet Microbe 2020, 1(1):e10.

14. van Doremalen N, Bushmaker T, Morris DH, Holbrook MG, Gamble A, Williamson BN: Aerosol and Surface Stability of SARS-CoV-2 as Compared with SARS-CoV-1. N Engl J Med 2020, 382:1564-1567.

15. Kampf G, Todt D, Pfaender S, Steinmann E: Persistence of coronaviruses on inanimate surfaces and their inactivation with biocidal agents. J Hosp Infect 2020, 104(3):246-251.

16. Springthorpe VS, Sattar SA: Chemical disinfection of virus-contaminated surfaces. Crit Rev Environ Control 1990, 20(3):169-229.
17. Rutala W, Weber D, Healthcare Infection Control Practices Advisory Committee: Guideline for Disinfection and Sterilization in Healthcare Facilities, 2008. Updated, 2019. Available at: https://www.cdc.gov/infectioncontrol/pdf/guidelines/ disinfection-guidelines-H.pdf.

18. World Health Organization Web Site. (2020). Retrieved June 6, 2020, from https://apps.who.int/iris/bitstream/handle/10665/332096/WHO-2019-nCoV

19. US Environmental Protection Agency Web site. (2020). Retrieved June 5, 2020, from https://www.epa.gov/pesticide-registration/list-n-disinfectants-use-against-sars-cov-2-covid-19

20. The International Pharmaceutical Federation Web site. (2020). Retrieved June 5, 2020, from https://www.fip.org/coronavirus

21. Centers for Disease Control and Prevention Web site. (2020). Retrieved June 6, 2020, from https://www.cdc.gov/ coronavirus/2019-ncov/hcp/pharmacies.html

22. Casey ML, Hawley B, Edwards N, Cox-Ganser JM, Cummings KJ: Health problems and disinfectant product exposure among staff at a large multispecialty hospital. Am J Infect Control, 2017, 45(10):1133-1138.

23. Dumas O, Varraso R, Boggs KM, Quinot C, Zock JP, Henneberger PK, Speizer FE, Le Moual N, Camargo CAJr: Association of occupational exposure to disinfectants with incidence of chronic obstructive pulmonary disease among US female nurses. JAMA Netw Open 2019, 2(10):e1913563.

24. Weinmann T, Forster F, von Mutius E, Vogelberg C, Genuneit J, Windstetter D, Nowak D, Radon K, Gerlich J: Association between occupational exposure to disinfectants and asthma in young adults working in cleaning or health services: results from a cross-sectional analysis in Germany. J Occup Environ Med 2019, 61(9):754-759.

25. Institute of Medicine (US). (2000). Committee on the Assessment of Asthma and Indoor Air. Clearing the Air: Asthma and Indoor Air Exposures. Washington (DC): National Academies Press (US); 6, Indoor Chemical Exposures. Available from: https://www.ncbi.nlm.nih.gov/books/NBK224471/

26. Choi HY, Lee YH, Lim CH, Kim YS, Lee IS, Jo JM, Lee HY, Cha HG, Woo HJ, Seo DS: Assessment of respiratory and systemic toxicity of Benzalkonium chloride following a 14day inhalation study in rats. Part Fibre Toxicol 2020, 17(1):5.

27. Goh CF, Ming LC, Wong LC: Dermatologic reactions to disinfectant use during the COVID-19 pandemic. Clin Dermatol 2020. Doi: 10.1016/j.clindermatol.2020.09.005

28. Chang A, Schnall AH, Law R, Bronstein AC, Marraffa JM, Spiller HA, Hays HL, Funk AR, Mercurio-Zappala M, Calello DP: Cleaning and disinfectant chemical exposures and temporal associations with COVID-19 - National Poison 
Data System, United States, January 1, 2020-March 31, 2020. MMWR Morb Mortal Wkly Rep, 2020, 69(16):496-.498.

29. Medina-Ramon M, Zock JP, Kogevinas M, Sunyer J, Torralba Y, Borrell A, Burgos F, Anto JM: Asthma, chronic bronchitis, and exposure to irritant agents in occupational domestic cleaning: a nested case-control study. Occup Environ Med 2005, 62(9), 598-606.

30. Cohle SD, Thompson W, Eisenga BH, Cottingham SL: Unexpected death due to chloramine toxicity in a woman with a brain tumor. Forensic Sci Int 2001, 124(2-3):137-139.

31. Bracco D, Dubois MJ, Bouali R: Intoxication by bleach ingestion. Can J Anaesth 2005, 52(1):118-119.

32. National Research Council (NRC). (2004). Acute Exposure Guideline Levels for Selected Airborne Chemicals: Volume 4 Washington, DC: The National Academies Press. https://doi. org/10.17226/10902

33. CDC. (2020). Cleaning and disinfection for households. https://www.cdc.gov/coronavirus/2019-ncov/prevent-gettingsick/cleaning-disinfection.html

34. Rahmani AR, Azarian G, Poormohammadi A: Health Impacts of Long-term Exposure to Disinfectants During SARS-Cov-2 Pandemic. Avicenna J Environ Health Eng 2020, 7(1):53-54.

35. McDonnell G, Russell AD: Antiseptics and disinfectants: activity, action, and resistance. Clin Microbiol Rev 1999, 12(1):147-179.

36. Dellanno C, Vega Q, Boesenberg D: The antiviral action of common household disinfectants and antiseptics against murine hepatitis virus, a potential surrogate for SARS coronavirus. Am J Infect Control 2009, 37(8):649-652.

37. Dong F, Chen J, Li C, Ma X, Jiang J, Lin Q, Lin C, Diao H: Evidence-based analysis on the toxicity of disinfection byproducts in vivo and in vitro for disinfection selection. Water Res 2019, 165:114976.

38. Addie DD, Boucraut-Baralon C, Egberink H, Horzinek M, Hosie M, Lloret A, Lutz H, Marsilio F, Pennisi M, Radford A, Thiry E, Truyen U, Möstl K, European Advisory Board on Cat Diseases: Disinfectant choices in veterinary practices, shelters and households $\mathrm{ABCD}$ guidelines on safe and effective disinfection for feline environments. J Feline Med Surg 2015, 17(7):594-605.

39. Melin VE, Melin TE, Dessify BJ, Nguyen CT, Shea CS, Hrubec TC: Quaternary ammonium disinfectants cause subfertility in mice by targeting both male and female reproductive processes. Reprod Toxicol 2016, 59:159-166.

40. Lawrence WH, Dillingham EO, Turner JE, Autian J: (1972). Toxicity profile of chloroacetaldehyde. J Pharm Sci 61(1):1925 .
41. New Jersey Department of Hralth and senior Services. Chloroacetaldehyde. Hazardous substance Fact Sheet. Retrieved June 10, 2020, from https://nj.gov/health/eoh/rtkweb/documents/ fs/0372.pdf

42. European Chemicals Agency (ECHA). Chloroacetaldehyde. Retrieved June 10, 2020, from https://echa.europa.eu/registration-dossier/-/registered-dossier/8143/7/2/2

43. Hauptmann M, Stewart PA, Lubin JH, Beane Freeman LE, Hornung RW, Herrick RF, Hoover RN, Fraumeni JFJr, Blair A, Hayes RB: (2009). Mortality from lymphohematopoietic malignancies and brain cancer among embalmers exposed to formaldehyde. J Natl Cancer Inst 2009, 101(24):1696-1708.

44. Hauptmann M, Lubin JH, Stewart PA, Hayes RB, Blair A: Mortality from lymphohematopoietic malignancies among workers in formaldehyde industries. J Natl Cancer Inst 2003, 95(21):1615-1623.

45. Beane Freeman L, Blair A, Lubin JH, Stewart PA, Hayes RB, Hoover RN, Hauptmann M: Mortality from lymphohematopoietic malignancies among workers in formaldehyde industries: The National Cancer Institute Cohort. J Natl Cancer Inst 2009, 101(10):751-761.

46. Tarka P, Kanecki K, Tomasiewicz K: Evaluation of chemical agents intended for surface disinfection with the use of carrier methods. Bactericidal, yeasticidal and sporocidal activity. Postep Mikrobiol 2016, 55(1):99-104.

47. Eggers M, Eickmann M, Zorn J: Rapid and effective virucidal activity of povidone-iodine products against middle east respiratory syndrome coronavirus (MERS-CoV) and modified vaccinia virus Ankara (MVA). Infect Dis Ther, 2015, 4(4):491501. 